\title{
The HIV-1 protease inhibitor indinavir impairs insulin signalling in HepG2 hepatoma cells
}

\author{
M. Schütt, M. Meier, M.Meyer, J. Klein, S.P. Aries, H.H. Klein \\ Department of Internal Medicine I, Medical University of Lübeck, Germany
}

\begin{abstract}
Aims/hypothesis. Patients treated with human immunodeficiency virus-1 protease inhibitors often develop impaired glucose tolerance or diabetes, most likely due to an induction of insulin resistance. We therefore investigated whether the protease inhibitor indinavir alters insulin signalling.

Methods. We incubated HepG2 cells for $48 \mathrm{~h}$ without or with indinavir $(100 \mu \mathrm{mol} / \mathrm{l})$. Subsequently ${ }^{125} \mathrm{I}$-insulin binding to the cells and the effects of insulin stimulation on insulin-receptor substrate-1-phosphorylation, association of phosphatidylinositol 3-kinase with insulin-receptor substrate-1 and Akt-Thr ${ }^{308}$ phosphorylation were measured.

Results. In cells not exposed to indinavir, insulin (100 $\mathrm{nmol} / \mathrm{l}$ ) led to rapid increases of insulin-receptor substrate-1-phosphorylation, association of phosphati-
\end{abstract}

dylinositol 3-kinase with insulin-receptor substrate-1 and Akt-phosphorylation during the first $75 \mathrm{~s}$, followed by subsequent decreases. In indinavir-treated cells, these insulin-stimulated increases during the first $75 \mathrm{~s}$ were reduced by $30-60 \%$ and this was not associated with alterations in cell number or viability, insulin binding to the cells or cellular insulin-receptor substrate-1-content.

Conclusion/interpretation. Effects of indinavir on initial insulin signalling could cause, or contribute to, the metabolic effects of human immunodeficiency virus-1 protease inhibitors. [Diabetologia (2000) 43: 1145-1148]

Keywords HIV protease inhibitors, lipodystrophy syndrome, diabetes mellitus, insulin resistance, insulin signalling.
Patients treated with human immunodeficiency virus-1 (HIV-1) protease inhibitors frequently develop IGT or diabetes [1]. The underlying cause seems to be a protease inhibitor-induced insulin resistance [1]. We investigated potential molecular mechanisms by which the protease inhibitor indinavir might alter insulin signalling and in this way trigger insulin resistance.

Cellular insulin signalling is initiated by binding to its specific cell surface receptors, followed by rapid

Received: 8 March 2000 and in revised form: 31 May 2000

Corresponding author: Dr. H.H. Klein, Department of Internal Medicine I, Medical University of Lübeck, Ratzeburger Allee 160, 23538 Lübeck, Germany

Abbreviations: HIV-1, Human immunodeficiency virus-1; PI 3kinase, phosphatidylinositol 3-kinase. phosphorylation of tyrosine residues on the receptor $\beta$-subunit [2]. This results in activation of the insulinreceptor kinase towards tyrosine-containing sites of a number of intracellular target proteins. Phosphorylation of these insulin-receptor substrates is thought to play a major part in the transduction of the insulin signal [2]. An important substrate is IRS-1. Once it is phosphorylated by the insulin receptor, several other intracellular proteins bind to IRS-1 and further propagate the insulin signal [2]. Among these is phosphatidylinositol 3-kinase (PI 3-kinase), a lipid kinase, which upon binding to IRS-1 is activated and which seems to be essential for the signalling that leads to the initiation of glucose transport [2]. It is likely that this downstream signalling involves activation of Akt by $\mathrm{Thr}^{308} / \mathrm{Ser}^{473}$-phosphorylation [2]. To investigate whether indinavir alters insulin signalling, we 
measured insulin-stimulated IRS-1-phosphorylation, association of PI 3-kinase with IRS-1 and Akt$\mathrm{Thr}^{308}$-phosphorylation in HepG2 hepatoma cells treated without or with indinavir.

\section{Materials and methods}

Materials. Fetal calf serum (FCS) was purchased from Biochrom (Berlin, Germany), Leibovitz-L15 medium from Gibco (Karlsruhe, Germany) and $\left.{ }^{125} \mathrm{I}-\mathrm{Tyr}-\mathrm{A}^{14}\right]$-monoiodoinsulin from Amersham (Braunschweig, Germany). Antibodies against IRS-1 and PI 3-kinase $85000 \mathrm{M}_{\mathrm{r}}$-regulatory subunit were from Upstate Biotechnology (Lake Placid, N. Y., USA), anti-phosphotyrosine antibody from Transduction Laboratories (Lexington, Ky., USA) and Akt and $\mathrm{Th}^{308}$-phosphorylated Akt antibodies from New England BioLabs (Beverly, Mass., USA). Peroxidase-labelled antibodies came from Dako (Glostrup, Denmark); other chemicals were from Sigma (Deisenhofen, Germany) or Roche (Mannheim, Germany). Indinavir was from Merck\&Co. (Rahway, N.J., USA).

Preparation of indinavir stock solution and cell incubation. To prepare indinavir stock solution, $35.6 \mathrm{mg}$ indinavir powder (purity $\geq 99.5 \%$ according to manufacturer) were dissolved in $1 \mathrm{ml} 6.25 \% \mathrm{HCl}$. This was added to Leibovitz- 15 medium and the $\mathrm{pH}$ adjusted to 7.4 with $\mathrm{NaHCO}_{3}$ (final volume $100 \mathrm{ml}$ ). Stock solution without indinavir was similarly prepared, except that the $\mathrm{HCl}$ did not contain indinavir. HepG2 cells that had grown to near confluency (Leibovitz-15 medium supplemented with $10 \% \mathrm{FCS}, 5 \mathrm{mmol} / \mathrm{l}$ glucose, $2.5 \mu \mathrm{l} / \mathrm{ml}$ transferrin, $60 \mu \mathrm{g} / \mathrm{ml}$ fetuin and $20 \mu \mathrm{g} / \mathrm{ml}$ gentamicin at $37^{\circ} \mathrm{C}$ ) were then incubated for $24 \mathrm{~h}$ with $16 \mathrm{ml}$ fresh Leibovitz-15 medium to which $4 \mathrm{ml}$ of the stock solutions without or with indinavir (final concentration $100 \mu \mathrm{mol} / \mathrm{l}$ ) had been added. This medium was replaced by fresh medium that was similarly prepared, except that it now contained only $1 \%$ FCS, and the incubation continued for $24 \mathrm{~h}$. We chose $48 \mathrm{~h}$ of incubation without or with $100 \mu \mathrm{mol} / \mathrm{l}$ indinavir because preceding experiments had shown that indinavir more strongly inhibited insulin-stimulated IRS-1-phosphorylation after $48 \mathrm{~h}(35 \%)$ than after 24 $(24 \%)$ and $8 \mathrm{~h}(17 \%)$ and that $100 \mu \mathrm{mol} / \mathrm{l}$ indinavir was more potent $(33 \%)$ than $10 \mu \mathrm{mol} / \mathrm{l}(15 \%$; data not shown).

Cell number and viability. Cells were counted in a Neubauer chamber and viability tested with trypane blue exclusion.

Insulin binding. Insulin binding to the cells was measured as described previously [3]. Briefly, cells were preincubated for $15 \mathrm{~min}$ with incubation buffer $(20 \mathrm{mmol} / \mathrm{l} \mathrm{HEPES}, 130 \mathrm{mmol} / \mathrm{l}$ $\mathrm{NaCl}, 4.8 \mathrm{mmol} / \mathrm{l} \mathrm{KCl}, 1.3 \mathrm{mmol} / 1 \mathrm{KH}_{2} \mathrm{PO}_{4}, 1 \mathrm{~g} / \mathrm{l}$ D-glucose, $\left.1.3 \mathrm{mmol} / \mathrm{l} \mathrm{MgSO}_{4}, 1.2 \mathrm{mmol} / 1 \mathrm{CaCl}_{2}, 2 \% \mathrm{BSA}, \mathrm{pH} 7.4\right)$ that contained 0 or $100 \mu \mathrm{mol} / \mathrm{l}$ indinavir. This buffer was then replaced by fresh incubation buffer without and with indinavir, and after another preincubation for $15 \mathrm{~min} 0.17 \mathrm{nmol} / \mathrm{l}$ (final concentration) $\left[{ }^{125} \mathrm{I}-\mathrm{Tyr}-\mathrm{A}^{14}\right]$-monoiodoinsulin $\left(185 \cdot 10^{6} \mathrm{~Bq}^{-1}\right.$. $\mathrm{mmol}^{-1}$ ) and different concentrations of unlabelled insulin were added. After different time periods the buffer was removed and dishes washed with a solution that contained $154 \mathrm{mmol} / \mathrm{l} \mathrm{NaCl}$ and $10 \mathrm{mmol} / \mathrm{l}$ TRIS, pH 7.4. Cells were detached with $1 \%$ Triton X-100, collected and associated radioactivity detected.

Insulin stimulation and solubilization of cells. We preincubated cells as described for insulin binding. We then added 0 or 100 $\mathrm{nmol} / \mathrm{l}$ insulin (final concentration) and incubated cells for different times at $37^{\circ} \mathrm{C}$. Subsequently, the buffer was removed and the dishes with the cells rapidly frozen in liquid nitrogen. The thin ice layer with the cells was scraped off from the dishes at $-20^{\circ} \mathrm{C}$ and homogenized with a motor-driven Potter homogenizer in $1 \%$ Triton X-100, $5 \mathrm{mmol} / \mathrm{l}$ phenylmethylsulphonylfluoride, $800 \mathrm{U} / \mathrm{ml}$ aprotinin, $8 \mathrm{mmol} / \mathrm{l}$ EDTA, $30 \mathrm{mmol} / \mathrm{l} \mathrm{benz-}$ amidine, $2.5 \mu \mathrm{g} / \mathrm{ml}$ pepstatin, $2.5 \mu \mathrm{g} / \mathrm{ml}$ leupeptin, $160 \mathrm{mmol} / \mathrm{l}$ $\mathrm{NaF}, 10 \mathrm{mmol} / 1$ sodium pyrophosphate, $0.2 \mathrm{mmol} / 1$ sodium vanadate, $2 \mathrm{mmol} / \mathrm{l}$ dichloroacetic acid and $20 \mathrm{mmol} / \mathrm{l} \mathrm{HEPES}$, $\mathrm{pH} 7.4$ (final concentrations). Samples were then centrifuged at $10^{5} \mathrm{~g}\left(4^{\circ} \mathrm{C}\right)$ to remove insoluble material and protein concentrations measured.

Immunoblots. We incubated solubilized cells ( $300 \mu \mathrm{g}$ protein) overnight with $1 \mu \mathrm{g}$ anti-IRS-1-antibody and then added them to $30 \mu \mathrm{l}$ packed agarose beads cross-linked with protein $\mathrm{G}$. These were shaken $30 \mathrm{~s}$ every $5 \mathrm{~min}$ for $12 \mathrm{~h}$ and then washed. Bound proteins were detached with Laemmli-buffer, boiled and subjected to SDS-PAGE. For measurement of $\mathrm{Thr}^{308}$-phosphorylated Akt, cell lysates (100 $\mu$ g protein) were directly subjected to SDS-PAGE $(7.5 \%)$. Proteins were then transferred to nitrocellulose (phosphotyrosine, p85, Akt and phospho-Akt blots) or polyvinylidene difluoride-membranes (IRS-1 blots). Membranes were blocked in $10 \%$ block mix (Boehringer Mannheim, Germany) or $5 \%$ skim, milk, respectively and incubated with the specific antibodies for $2 \mathrm{~h}$. Bound antibodies were detected by peroxidase-labelled antibodies and chemiluminescence.

Data analysis. In every western blot we compared eight bands (four time points \pm indinavir) by scanning densitometry. Arbitrary units represent the ratio between the intensity of the single bands and the mean intensity of all eight bands in the same blot. Differences were tested by $t$ statistics for paired data. We considered a $p$ value of 0.05 or less to be significant.

\section{Results}

Cell number and viability. Indinavir had no effect on cell number $\left(1.7 \times 10^{6} \pm 0.16\right.$ and $1.7 \times 10^{6} \pm 0.13$

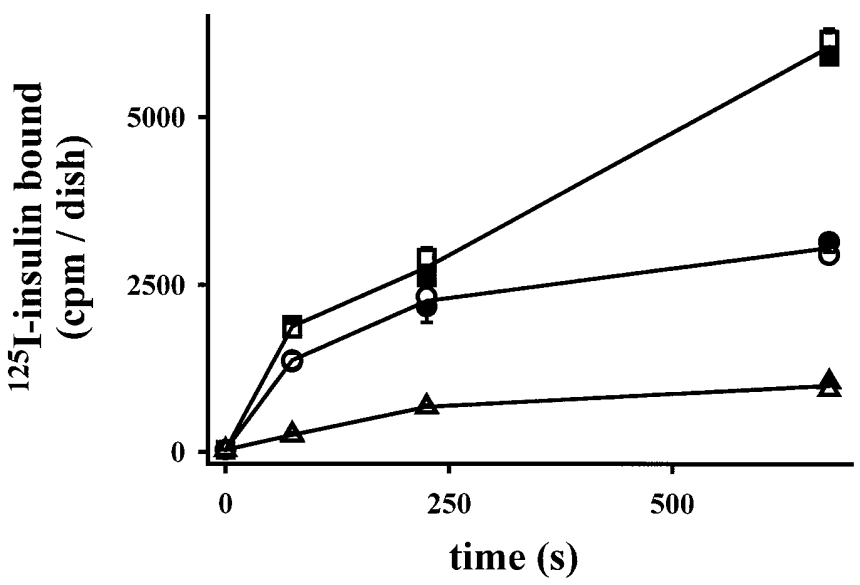

Fig. 1. ${ }^{125}$ I-Insulin binding. Cells were incubated without $(\square$, $\bigcirc, \triangle$ ) or with $(\boldsymbol{\square}, \mathbf{O}, \boldsymbol{\Delta}) 100 \mu \mathrm{mol} / \mathrm{l}$ indinavir for $48 \mathrm{~h}$ as described. Subsequently, insulin binding was measured as described with $0.17 \mathrm{nmol} / \mathrm{l}^{125} \mathrm{I}$-insulin and $0(\square, \mathbf{\square}), 3.3(\bigcirc, \mathbf{O})$, or $3300 \mathrm{nmol} / \mathrm{l}(\boldsymbol{\Delta}, \triangle)$ unlabelled insulin. After the indicated times cells were washed and transferred for gamma-counting. Data represent means $\pm \mathrm{SEM}, n=3$ 

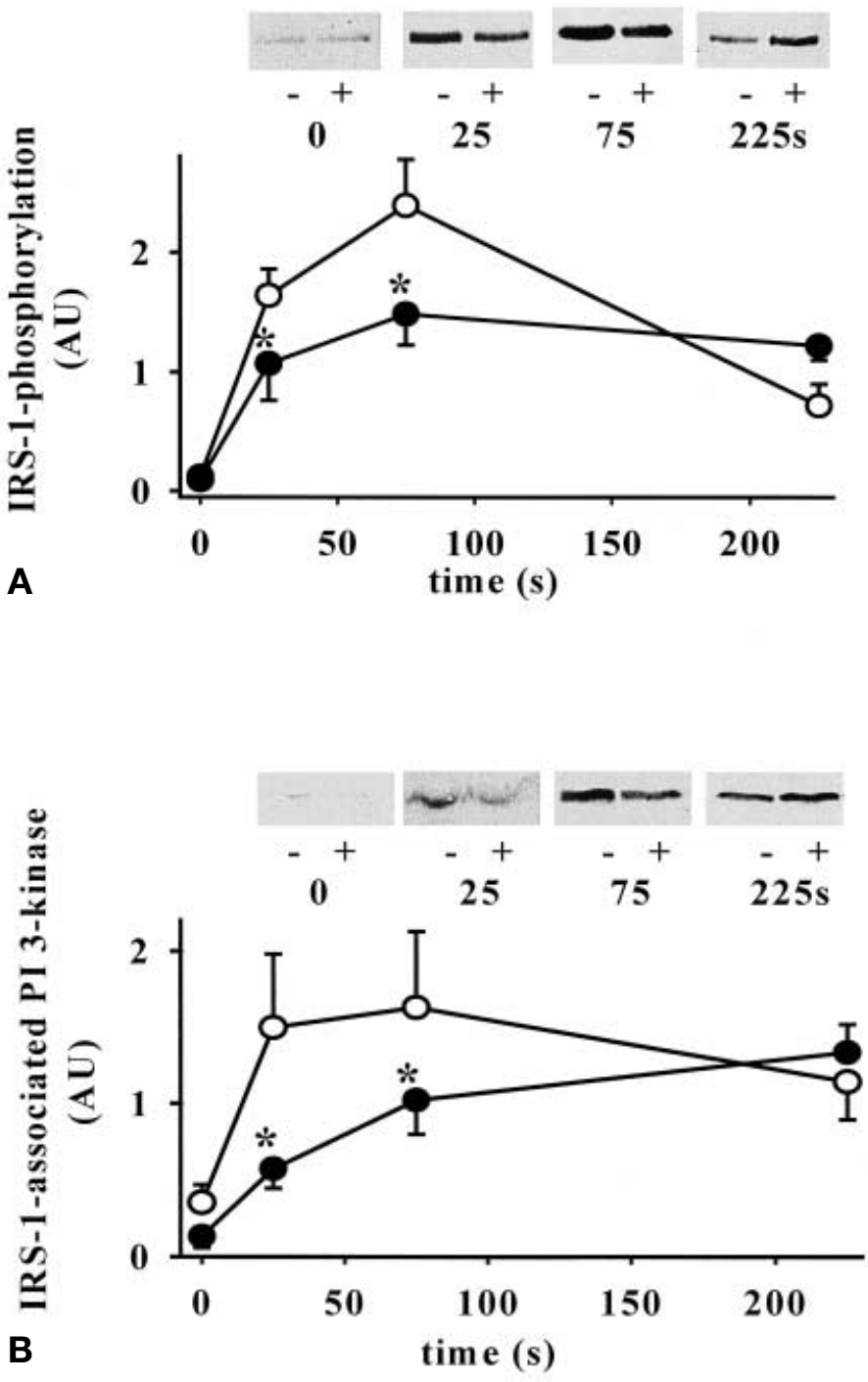

Fig. 2A-D. Effect of indinavir on IRS-1-phosphorylation (A), association of PI 3-kinase with IRS-1 (B), IRS-1-amount (C) and Akt-phosphorylation (D). Cells were incubated without (O) or with (O) $100 \mu \mathrm{mol} / 1$ indinavir for $48 \mathrm{~h}$ and then stimulated with 0 or $100 \mathrm{nmol} / \mathrm{l}$ insulin for the indicated times. They were then solubilized and IRS-1 immunoimmobilized with anti-IRS-1-antibody bound to protein $\mathrm{G}$ agarose beads. The beads were washed, bound proteins detached with Laemmlibuffer and immunoblots done as described in Methods. $\mathrm{Thr}^{308}$-phosphorylated Akt in cell lysates was measured by immunoblot with specific anti-phospho-Akt antibody. AU were calculated as described. Shown are means \pm SEM $(n=5)$, $* p \leq 0.05$. Insets show representative blots \pm indinavir at the respective time points

cells/dish treated without or with indinavir, respectively) or cell viability $(9.7 \pm 0.4$ and $9.7 \pm 0.4 \%$ trypane positive cells/dish, respectively). Moreover, there were no detectable morphological changes between cells treated without or with indinavir (data not shown).
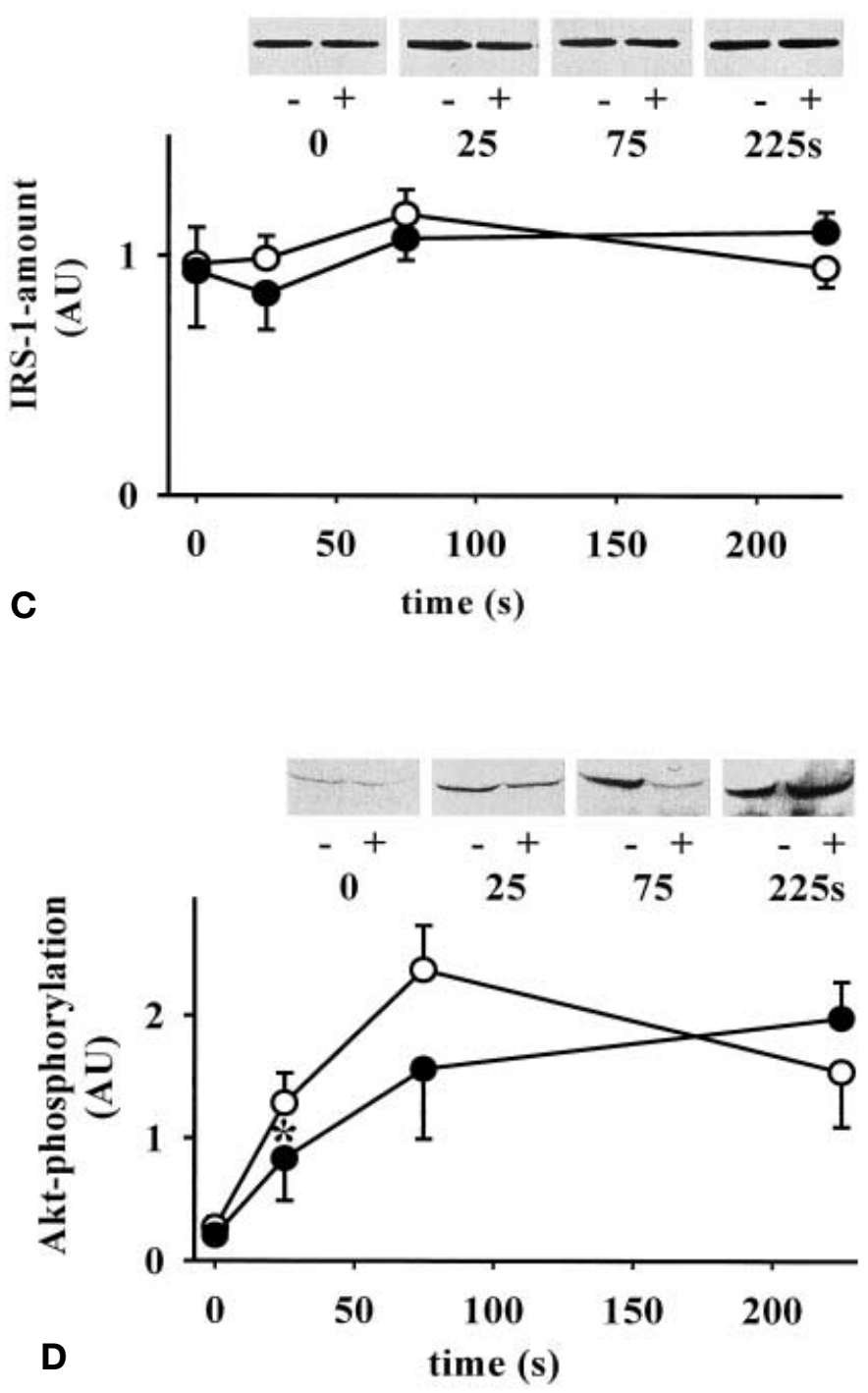

${ }^{125}$ I-Insulin binding. Insulin association with the cells at the trace insulin concentration $\left(0.17 \mathrm{nmol} / \mathrm{l}^{125} \mathrm{I}\right.$-insulin) and at a concentration that resulted in approximately $50 \%$ competition $(3.3 \mathrm{nmol} / \mathrm{l})$ was not affected by indinavir (Fig. 1). Non-specific insulin binding $(3300 \mathrm{nmol} / \mathrm{l})$ was also not different.

IRS-1-phosphorylation, association of PI 3-kinase with IRS-1 and Akt-phosphorylation. In cells not preincubated with indinavir insulin rapidly increased IRS-1-phosphorylation, association of PI 3-kinase with IRS-1 and $\mathrm{Thr}^{308}$-phosphorylation of Akt (Fig. 2). The greatest effects were observed after $75 \mathrm{~s}$, followed by subsequent decreases. Preincubation with indinavir reduced insulin-stimulated IRS-1phosphorylation and association of PI 3-kinase with IRS- 1 at the 25 and 75 s points by $30-60 \%$. A similar reduction was observed for Akt-phosphorylation, except that the difference at $75 \mathrm{~s}$ did not reach statistical significance. At $225 \mathrm{~s}$ no effects were observed between cells treated without or with indinavir. Indinavir had no effects on the amounts of IRS-1 (Fig.2) or Akt (data not shown). 


\section{Discussion}

We show that incubation of HepG2 cells with the HIV-1 protease inhibitor indinavir for $48 \mathrm{~h}$ resulted in reduced insulin effects on initial IRS-1-tyrosinephosphorylation, association of PI 3-kinase with IRS-1 and $\mathrm{Thr}^{308}$-phosphorylation of Akt. Such indinavir effects on important steps of the initial insulin signalling cascade could represent a mechanism that could, at least partially, be responsible for the protease inhibitor-induced insulin resistance.

We chose HepG2 cells because they represent an established human cell model and allow the investigation of long-term effects [3]. Insulin stimulation of cells that had not been exposed to indinavir resulted in rapid increases of IRS-1-phosphorylation, association of PI 3-kinase with IRS-1 and Thr ${ }^{308}$-phosphorylation of Akt followed by decreases to approximately $40-60 \%$ of the peak levels. Such biphasic kinetics of insulin signalling have also been described in previous studies with HepG2 cells and other cell systems [4,5] and could be caused, among other things, by feed-back mechanisms or compartmentalization and trafficking of signalling molecules or both within the cells $[2,5]$.

It is not clear whether an indinavir-induced reduction of insulin-stimulated IRS-1-phosphorylation, association of PI 3-kinase with IRS-1 and Thr ${ }^{308}$-phosphorylation of Akt in the initial phase of insulin signalling, as we observed, could by itself lead to insulin resistance. It is, however, possible that the "initial burst" in signalling by the early insulin signalling elements is important for the signalling to more longlasting downstream intermediates [6]. Therefore the indinavir-induced impairment of the initial rise in insulin signalling that we observed could result in sustained reductions in later signals and downstream biological effects. In any case, our finding that indinavir interferes at all with the activation of initial elements of the insulin signalling cascade implies that such interference could cause, or contribute to, the metabolic effects of indinavir.

It is not clear by which mechanism indinavir might exert its effects on insulin signalling. Our finding that insulin-binding to the cells was not altered by indinavir suggests that indinavir influences IRS-1-phosphorylation, association of PI 3-kinase with IRS-1 and Akt-phosphorylation by mechanisms on the postbinding level. Potential mechanisms include a HIV-1 protease inhibitor-mediated inhibition of the proteolysis of certain phosphotyrosine-phosphatases or serine kinases that are involved in the regulation of insulin signalling [2]. A high specificity of indinavir for the HIV-1 protease has, however, been shown [7]. Alternatively, indinavir, which is approximately $60 \%$ homologous with regions of the cytoplasmic retin- oid-acid binding protein type-1, might lead to decreased stimulation of the retinoid $\mathrm{X}$ receptor (RXR) [8]. This receptor, together with the peroxisomal proliferator-activated receptor gamma (PPAR $\gamma$ ) has been shown to participate in the regulation of insulin sensitivity [9] and RXR/PPAR $\gamma$-stimulation has been found to be associated with increased insulin-stimulated IRS-1-phosphorylation and PI 3-kinase activity [10].

Although the mechanism is still not known, we provide evidence that treatment with the protease inhibitor indinavir impairs initial insulin signalling. Such an interference of indinavir with insulin signal transduction could, at least in part, represent a molecular basis for its metabolic effects.

Acknowledgements. This study was supported by the German Research Foundation (KI 503/7-3) and the Medical University of Lübeck's research support programme (1398-J26). The study contains data from the thesis of Markus Meier. The expert technical assistance by M. Drenckhan is appreciated.

\section{References}

1. Walli R, Herfort O, Michl GM et al. (1998) Treatment with protease inhibitors associated with peripheral insulin resistance and impaired oral glucose tolerance in HIV-1-infected patients. AIDS 12: 167-173

2. Virkamäki A, Ueki K, Kahn CR (1999) Protein-protein interaction in insulin signalling and the molecular mechanisms of insulin resistance. J Clin Invest 103: 931-943

3. Hofmann C, Marsh JW, Miller B, Steiner DF (1980) Cultured hepatoma cells as a model system for studying insulin processing and biologic responsiveness. Diabetes 29: 865-874

4. Kim SJ (1998) Insulin rapidly induces nuclear translocation of PI3-kinase in HepG2 cells. Biochem Mol Biol Int 46: 187-196

5. Inoue G, Cheatham B, Emkey R, Kahn CR (1998) Dynamics of insulin signalling in 3T3-L1 adipocytes. J Biol Chem 273: 11548-11555

6. Kim YB, Zhu JS, Zierath JR, Shen HQ, Baron AD, Kahn BB (1999) Glucosamin infusion in rats rapidly impairs insulin stimulation of phosphoinositide 3-kinase but does not alter activation of Akt/protein kinase B in skeletal muscle. Diabetes 48: 310-320

7. Balani SK, Woolf EJ, Hoagland VL et al. (1996) Disposition of indinavir, a potent HIV-1 protease inhibitor, after an oral dose in humans. Drug Metab Dispos 24: 1389-1394

8. Carr A, Samara K, Chisholm DJ, Cooper DA (1998) Pathogenesis of HIV-1-protease inhibitor-associated peripheral lipodystrophy, hyperlipidaemia, and insulin resistance. Lancet 351: 1881-1883

9. Mukherjee R, Davies PJ, Crombie DL et al. (1997) Sensitization of diabetic and obese mice to insulin by retinoid $\mathrm{X}$ receptor agonists. Nature 386: 407-410

10. Peraldi P, Xu M, Spiegelman BM (1997) Thiazolidinediones block tumor necrosis factor- $\alpha$-induced inhibition of insulin signalling. J Clin Invest 100: 1863-1869 